\title{
Australian Union Transformation and the Challenge for Labour Historians
}

\author{
Bradley Bowden*
}

The purpose of this article is two-fold. First, it confronts misconceptions that explain union decline in Australia; misconceptions that are entrenched in labour history and industrial relations scholarship. We are told that decline "commenced in the early 1980s," when in fact it began in 1948; that union decline primarily results from attacks by conservative governments "bent on their destruction," when the rate of decline has often been steepest under Labor governments; that unions invariably redress the plight of society's poorest, when union agreements negotiated in retail and hospitality routinely leave workers in a worse position than those employed under relevant awards. The article's second purpose is to trace the sociological consequence of union decline. While unions claim to speak for society's battlers, more than 40 per cent of unionists today are managers and professionals. In terms of wage cohorts, the propensity to join increases with wealth. Although unions retain representation rights for society's battlers, and publicly advocate their cause, the fact remains: society's poorest members are no longer found in much number in union ranks. In part, at least, the unwillingness of labour historians to confront harsh realities stems from an understandable desire to defend labour's cause, rather than serve primarily as dispassionate academic observers.

Keywords: Union Decline, ACTU, SDA, Canadian Unionism, American Unionism, Workforce Change

Although the study of labour history covers a wide ambit (class, gender, race, etc), it is nevertheless the case that trade unionism has been central to the work of this journal since its inception. Of the four articles in the first edition of the Bulletin for the Society for the Study of Labour History, one - on "Queensland Labour History" - was by Joe Harris, a long-term official of the Building Workers Industrial Union. Two others, by Bede Nairn and Geoffrey Bolton, dealt with the history of organised labour in New South Wales and Charters Towers, respectively. ${ }^{1}$ Over the subsequent decades, many of us

* The author would like to thank Labour History's two anonymous referees.

1. W. J. H. Harris, "Queensland Labour History," Bulletin for the Society for the Study of Labour History, no. 1 (January 1962): 16-24; W. B. Nairn, "Some Aspects of the Social Role of the Labour Movement in New South Wales in the 1870s," Bulletin for 
have enjoyed the benefices of trade unions; a benefice bestowed in the form of PhD scholarships, book projects and unrestricted access to union archives. For most there was a shared consensus that unions act in the common good; that the "labour movement is," as Ian Turner declared, "the institutional method by which the masses transform themselves from passive to active elements in society." ${ }^{2}$ As decline gathered pace in Australia, however, the union movement's diminution posed an existential threat to the cultural and intellectual traditions that unionism helped foster: including labour history. For many, understanding and reversing the process of union decline became an imperative. Subsequently, whether by accident or design, the explanations for union decline provided by labour historians and industrial relations academics at any particular point in time have tended to accord with the then current "revitalisation strategies" tendered by the Australian Council of Trade Unions (ACTU). In the 1980s and early 1990s, "productivity" was the elixir that would boost not only union membership but also allow the elimination of work patterns based on "authoritarian supervision."3 Echoing this opinion, David Peetz advised readers of the Journal of Industrial Relations that, "[e]mployers will encourage unionisation if this gives them an advantage in terms of productivity or flexibility."4 Such views corresponded with an international literature on the supposed productivity-enhancing (and union-enhancing) effects of "collective voice" in the workplace. 5 As hopes in the revitalising effects of productivity faded, research agendas were increasingly associated with the "Organising Model," which became ACTU policy in 1994. In 2002, a special issue of Labour History was given over to "mobilising and organising"; a special edition which the then ACTU secretary, Greg Combet, opened with the observation that: "The critical role of active workplace organising in building the success of the Australian movement has become a neglected part of our history."6 In the issue's lead article, Rae Cooper and Greg Patmore claimed "urgency" existed in relation to understandings of organising strategies; an urgency indicated by the

the Society for the Study of Labour History, no. 1 (January 1962): 6-15; G. C. Bolton, "Labour Comes to Charters Towers," Bulletin for the Society for the Study of Labour History, no. 1 (January 1962): 25-34.

2. Ian Turner, Industrial Labour and Politics (Canberra: Australian National University Press, 1965), xvii.

3. Australian Council of Trade Unions/Trade Development Commission, Australia Reconstructed (Canberra: Australian Government Printing Service, 1987), 135.

4. David Peetz, "Unions, Conflict and the Dilemma of Cooperation," Journal of Industrial Relations 38, no. 4 (1996): 14. See also Ian Hampson, Peter Ewer and Meg Smith, "Post-Fordism and Workplace Change," Journal of Industrial Relations 36, no. 2 (1994): 231-57.

5. Richard B. Freeman and James L. Medoff, What Do Unions Do? (New York: Basic Books, 1984), 10, 15.

6. Greg Combet, “Introduction,” Labour History, no. 83 (November 2002): 1. 
fact that "Australian unions have haemorrhaged members."7 As it became evident, however, that the "organising" elixir had proved no more beneficial for the union patient than the earlier "productivity" tonic, so explanations increasingly centred upon another explanation that gained almost universal endorsement: neoliberalism. As Verity Burgmann recently observed in her Globalization and Labour in the Twenty-First Century: "From the 1970s onwards states rolled out abundant new rules ... [of] a neoliberal kind" as part of a "conscious strategy on the part of capital to increase exploitation of labour." ${ }^{8}$ Similarly, Sally McManus, the ACTU's current secretary, in explaining the motivation for the ACTU's (failed) Change the Rules campaign, declared in March 2018 that: "Australian workers are ruled by laws" that subject them to "the policies of unmitigated - oppressive - neo-liberalism." ${ }^{9}$

Despite the vast amount of research into union decline in Australia (and elsewhere) - research that has variously identified the key causal factors as being associated with "productivity," "organising" and "neo-liberalism" there remains extraordinary confusion as to the nature of union decline, its beginnings and its temporal progression. Almost invariably, union decline is discussed as if it was something that began in the 1980s. Thus we are advised by Peetz and Bailey that "decline in union density ... commenced in the early 1980s." ${ }^{10}$ The association of the 1980s with the commencement of union decline is also evident in Cooper and Patmore's analysis, where they state that: "Although density fell throughout the 1980s, it accelerated at an alarming rate in the early 1990s." 11 In fact, as Table 1 indicates, union decline in Australia is best perceived as a staged process, in which a generalised decline that began in 1948 was interrupted by a ten-year recovery between 1970 and 1979, after which decline recommenced. While the recovery of the 1970s was clearly associated with recruitment of white-collar and professional workers, the size of this rebound is difficult to gauge. During the 1970s, the Australian Bureau of Statistics (ABS) abandoned reliance on union membership returns (Labour and Industrial Branch Reports, cat. 6101.0).

7. Rae Cooper and Greg Patmore, "Trade Union Organising and Labour History," Labour History, no. 83 (November 2002): 3.

8. Verity Burgmann, Globalization and Labour in the Twenty-First Century (London: Routledge, 2016), 5.

9. Sally McManus, "Change the Rules: For More Secure Jobs and Fair Pay," speech to the Australian Press Club, 21 March 2018, Australian Council of Trade Unions, accessed January 2020, www.actu.org.au/actu-media/speeches-and-opinion/ sally-mcmanus-press-club-speech-change-the-rules-for-more-secure-jobs-andfair-pay.

10. David Peetz and Janis Bailey, "Neo-Liberal Evolution and Union Responses in Australia," in The International Handbook of Labour Unions: Responses to Neo-Liberalism, ed. Gregor Gall, Richard Hurd and Adrian Wilkinson (London: Edward Elgar Publishing, 2011), 70.

11. Cooper and Patmore, "Trade Union Organising and Labour History," 3. 
Table 1: Fall, Rise and Fall of Australian Union Density, 1948-2017

\begin{tabular}{cccc}
\hline Period & Length of Period & $\begin{array}{c}\text { Total Rise/Decline in } \\
\text { Union Density }\end{array}$ & $\begin{array}{c}\text { Annual Rate of Rise/ } \\
\text { Decline }\end{array}$ \\
\hline $1948-70$ & 23 years & $-15.9 \%$ & $-0.69 \%$ \\
$1970-79$ & 10 years & $7 \%$ & $0.7 \%$ \\
$1979-86$ & 8 years & $-4.9 \%$ & $-0.6125 \%$ \\
$1986-2017$ & 32 years & $-31 \%$ & $-0.97 \%$ \\
\hline
\end{tabular}

Bradley Bowden, Simon Blackwood, Catherine Rafferty and Cameron Allan, eds, Work \& Strife in Paradise: The History of Labour Relations in Queensland 1859-2009 (Sydney: Federation Press, 2009), Appendix 19, pp. 298-301

Subsequent datasets - Trade Unions Members, 1976-96 (cat. 6325.0), Employee Earnings, Benefits and Trade Unions, 1997-2013 (cat. 6310.1) and the current Characteristics of Employment, Australia (cat. 6333.0) - used labour force surveys. Accordingly, if one bases one's analysis on the "new" figures the rebound between 1970 and 1979 is 2 per cent (from 49 per cent to 51 per cent). By contrast, if one chooses the "old" figures the rebound is 7 per cent (from 49 per cent to 56 per cent). To avoid "understating" the 1970s rebound, Table 1 uses the "old" numbers for this period. To avoid "overstating" subsequent decline, it uses the "new" numbers to measure post-1979 circumstance (i.e. it measures recommencement of decline on a 50.3 per cent estimate, rather than a 56 per cent estimate)..$^{12}$

The staged process of union decline in Australia - which straddles a number of distinct historical periods - highlights the limitations of explanations whereby union decline is correlated to factors visible to the labour activist (i.e. laws, elections). Our training as historians should cause us to regard this approach with suspicion. As the French historian, Fernard Braudel, observed, the "events" that capture immediate attention are typically but "surface disturbances, crests of foam that the tides of history carry on their strong back." To write history that focuses solely on such events, Braudel continued, is to produce a variety of history that is "as short-sighted" as the popular imagination. ${ }^{13}$ The second challenge that confronts the labour historian in researching union decline is one

12. The best statistics on union membership are found in Bradley Bowden, Simon Blackwood, Catherine Rafferty and Cameron Allan, eds, Work E Strife in Paradise: The History of Labour Relations in Queensland 1859-2009, (Sydney: Federation Press, 2009), App. 19. Unless otherwise stated, membership figures are from this source.

13. Fernard Braudel, "Preface to the 1946 Edition," in Fernard Braudel, The Mediterranean and the Mediterranean World in the Age of Philip II, vol. 1, 2nd ed. (New York: Harper Torchbooks, 1975), 20. 
flagged by Rob Gollan in the introductory article to the first volume of this journal: "the question of partisanship." Gollan was also mindful of the tension between the role of the labour historian as activist and their professional duty as an historian. In Gollan's view, these roles can only be combined with care; a care that must give precedence to "a scrupulous regard for evidence." In addition, Gollan noted the need for Labour History to embrace research even by those "opposed to labour," for it is only through an openness to diverse explanation that we can hope to find the true cause of things. ${ }^{14}$

In structure, the remainder of this paper comprises two sections. The first explores not only the staged process of decline identified in Table 1, but also how Australian outcomes correspond to those found in countries with markedly different industrial relations systems, notably the USA and Canada. This uniformity of outcome, it is suggested, is indicative of the fact that variance in industrial relations law has only a modest impact on union decline. In the final section, we return to a consideration of the reasons put forward for union decline. Here, we argue that much of the debate has lacked balance and perspective. Too often, the complex process of union decline and transformation is ascribed to theoretical frameworks that fail to explain the marked variance of union decline across occupational sectors; a variance that has seen the union movement lose most of its historic constituency among blue-collar workers while gaining a new constituency of professionals and quasi-professionals in public administration, education and health.

\section{Union Decline: Stages, Causes and Consequences}

A consideration of the staged process of Australian union decline necessitates three basic conclusions. First, the initiation of the process of union decline (1948-70) cannot be attributed to factors such as "neoliberalism" or conservative governments "bent" on the "destruction" of unionism. ${ }^{15}$ These things lay in the future. Poor productivity should also be dismissed. The 1950s and 1960s were decades of high productivity. Similarly, lack of organising ability must be dismissed. The 1960s were years characterised by rising levels of workplace militancy. The second factor to note from Table 1 is that the "rebound" of the 1970s was of comparatively short duration. This is suggestive of some factor that was eroding union foundations even in this period of recovery. The third conclusion that is forced upon us by the figures

14. R. Gollan, "Labour History," Bulletin for the Society for the Study of Labour History, no. 1 (January 1962): 4-5.

15. David Peetz and Janice Bailey, "Dancing Alone? The Australian Union Movement Over Three Decades," Journal of Industrial Relations 54, no. 4 (2012): 531. 
recorded in Table 1 is that even if the institutional and legal frameworks (including those in relation to economic policy) had remained the same, it is almost certain that some decline would have happened anyway. Given that "neoliberalism" and less union-friendly laws only became significant factors from the mid-1980s it is tempting to attribute about a third of the post-1980s decline to such factors; a calculation based on the difference between the earlier and post-1986 rates of union decline. This is, however, a calculation that we cannot make on any sort of justifiable basis. It is possible that "neoliberalism" and legal changes contributed an outsized share of the post-1987 decline, rather than simply a third of the total. It is, however, also possible that the factors behind the earlier periods of decline gathered pace after 1986, contributing to more than two-thirds of the post-1986 decline. It is impossible to tell.

If we can attribute none of the pre-1986 period of decline to anti-union laws or "neoliberalism" and - in all probability - only a percentage of the post-1986 decline to these factors, then what can explain this prolonged process of decline? In this author's estimation, only one logical explanation presents itself: the gradual disappearance and dispersion of the manual blue-collar working class of factory workers, miners, shearers and seafarers who consistently made up around two-thirds of the Australian workforce between 1880 and the mid-1950s. Due to the effects of technology and, from the 1980s, increasing levels of globalised trade, this class withered away. In 1954, when unions claimed 62 per cent of the workforce as members, some 61.1 per cent of Australian workers laboured in industrial jobs. By 1981, only 42.75 per cent worked in such occupations, and by 2016 only 21.94 per cent. Significantly, occupational redundancy was paralleled by a process of geographic dispersion, as workers abandoned historic abodes in town centres for newer, more impersonal lives in the outer suburbs. As the industrial working class declined so too did the collectivist institutions that were once integral to its existence inside and outside the workplace: trade unions, socialist and Labor parties inspired by redistributive philosophies, friendly societies, retail co-operatives and various church-based charities. The correlation between union decline and the blue-collar share of the workforce is clearly indicated in Figure 1.16 Marching in lock-step until 1970, between 1970 and 1996 the correlation between union decline and blue-collar workforce share becomes less marked due to the 1970s union "rebound"; the degree of variance between the two lines depending on whether one uses the "old" union density figures (as Figure 1 indicates by 1976a) or the "new" ABS estimates (as

16. In calculating "blue-collar" the current ABS categories are used, ie agriculture, forestry and fishing; mining; manufacturing; electricity, gas, water and waste services; construction; transport, postal and warehousing. 


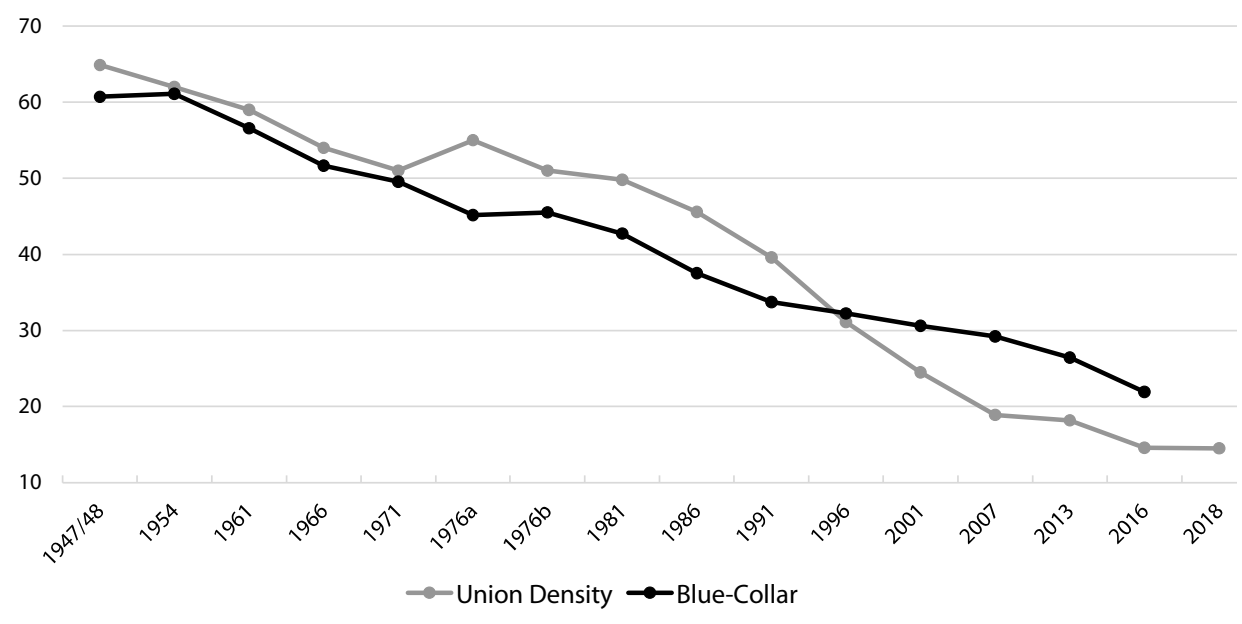

Figure 1: Union Density and Blue-Collar Workforce Share, 1947/48-2018

ABS, Labour and Industrial Branch Reports, cat. 6101.0; ABS, Trade Unions Members, cat. 6325.0; ABS, Employee Earnings, Benefits and Trade Union Membership, Australia, cat. 6310.0; ABS, Characteristics of Employment, Australia, cat. 6333.0; Bowden et al., Work \& Strife in Paradise, Appendix 21

Figure 1 indicates by 1976b). It is evident that this rebound was associated with an inrush of new recruits into areas of professional and whitecollar employment. Unfortunately for unions, since 1996 the comparative strength of trade unions among professional workers in public administration, education and health has not compensated for crumbling support amongst its historic constituency. Significantly, between 1986 and 2007 the presence or absence of conservative or Labor governments also made little difference to the rate of union decline. Indeed, during the 11 years of Labor rule between 1986 and 1996 union density fell at a sharper rate (by 14.5 percentage points, from 45.6 per cent to 31.1 per cent) than it did in the 12 years of the Howard government, when density declined by 12.2 percentage points (from 31.1 per cent to 18.9 per cent). While union density has fallen at a markedly slower rate since 2007 (falling by 4.4 percentage points to 14.5 per cent), it is again evident that the presence or absence of conservative governments has made little difference. This slowing in the rate of decline may be due to the passage of the Fair Work Act 2009. Alternatively, it may simply reflect the fact that union membership is approaching an absolute bedrock. What is nevertheless evident is that changes of government are in themselves of little consequence.

As blue-collar workers become a rare commodity within the union movement, the ranks of Australia's unions were more and more comprised of well-paid professionals. As Figure 2 indicates, by August 2016 those who 


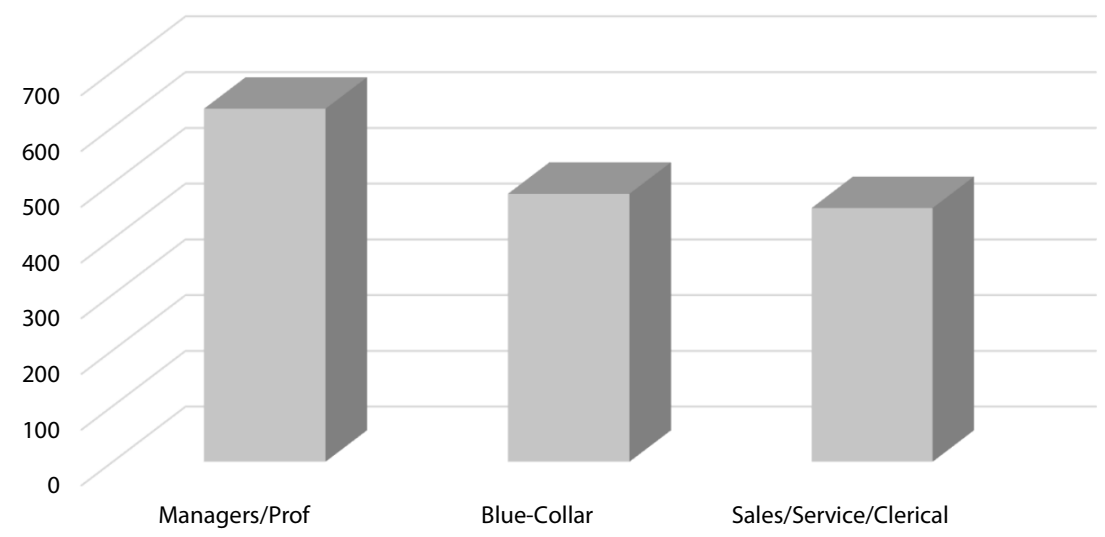

Figure 2: Social Composition of Australian Unionism, August 2016

ABS, Characteristics of Employment, Australia, August 2016, cat. 6333.0

listed their occupation as "manager" or "professional" $(633,200)$ far exceeded those who indicated they worked in either blue-collar work $(480,600)$ or a typically low-paid service, sales or clerical job $(455,100) \cdot{ }^{17}$

Significantly, the sociological transformation indicated in Figure 2 is not unique to Australia. Similar outcomes are discernible in countries with very different institutional environments, some of which (such as the USA) are seen as peculiarly hostile to unions, and others (such as Canada) being listed by the International Trade Union Confederation (ITUC) as far more unionfriendly. ${ }^{18}$ As Figure 3 reveals, however, in 2017-18 there was virtually no difference in the occupational composition of Australian, Canadian and US unions. In each case trade unions are increasingly dependent on the support of a relatively small part of the workforce employed in public sector, or quasi-public sector, areas such as public administration, emergency services, education and health. In the USA, these occupational cohorts make up 61 per cent of unionists. In Australia and Canada, these groups represent 58 per cent and 57.7 per cent of the total, respectively. By contrast, workers from retail, hospitality, art and recreation, personal services and the like make up a more significant (if still minuscule) proportion of unionists in

17. Australian Bureau of Statistics (ABS), Characteristics of Employment, Australia, August 2016, cat. 6333.0, Table 18 and Table 19. The occupational categories countered as "blue collar" here are those used by the ABS, namely: technicians and trade workers, machinery operators and drivers, labourers. Service workers are defined by the ABS as "community and personal services."

18. ITUC Global Rights Index 2018, International Trade Union Confederation, Geneva, accessed January 2020, www.ituc-csi.org/ituc-global-rights-index-2018. 


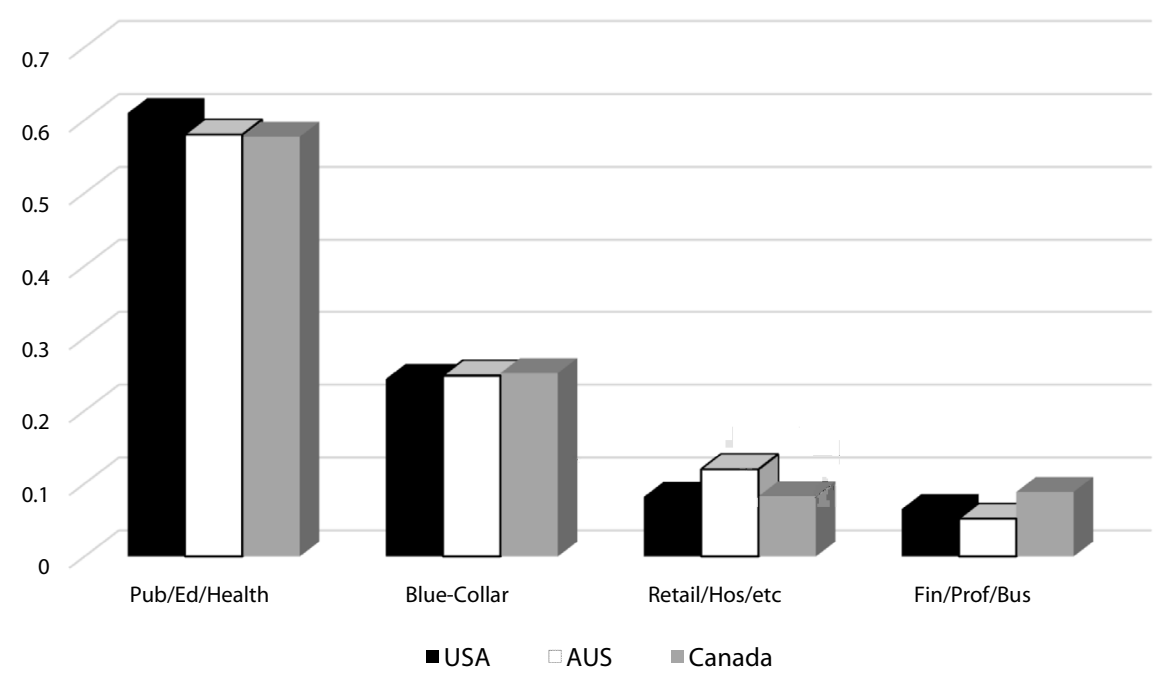

Figure 3: Occupational Distribution of Australian, Canadian and United States Membership, 2017-18

ABS, Characteristics of Employment, Australia, August 2018, cat. 6333.0, Table 3.1; Statistics Canada, "Union Status by Industry," 2013-17, Table 14-10-0132-01; United States Bureau of Labor Statistics, "Economic News Release," 19 January 2018, Table 3: Union Affiliation of Employed Wage and Salary Earners by Occupation and Industry, 2016-17. See footnote 19 for more reference information. Note: US figures do not include agricultural workers; Australian figures are for 2018; Canadian and United States figures are for 2017

Australia than is the case in either Canada or the USA; an outcome that belies the supposed importance of Canada's more union-friendly laws. Whereas in Australia these service-sector workers make up 11.97 per cent of all unionists, in both Canada and the USA they amount to 8.3 per cent. ${ }^{19}$

The almost identical occupational composition of union membership indicated in Figure 3 strongly suggests that the "sustained institutional protections" identified as key in the highly cited work of Bruce Western are not decisive factors in the propensity of different occupational groups to join

19. Calculated from: ABS, Characteristics of Employment, Australia, August 2018, cat. 6333.0, Table 3.1; Statistics Canada, "Union Status by Industry," 2013-17, Table 14-10-0132-01, accessed January 2020, www150.statcan.gc.ca/t1/tbl1/en/tv.action?pid=1410013201; United States Bureau of Labor Statistics, “Economic News Release," 19 January 2018, Table 3: Union Affiliation of Employed Wage and Salary Earners by Occupation and Industry, 2016-17, accessed January 2020, archived at, https://web.archive.org/ web/20180219022609/https://www.bls.gov/news.release/union2.t03.htm. US figures do not include agricultural workers; Australian figures are for 2018; Canadian and US figures are for 2017. 
unions. ${ }^{20}$ Rather it suggests that what we think of as "neoliberalism" - which Gall, Hurd and Wilkinson defined in their study into the supposed impact of "neoliberalism" on global union strength as an ideology supportive of "privatization, marketization, liberalization, deregulation, and reductions in state funding" 21 - has had markedly uneven societal outcomes. Initially associated the diminution of the occupational strength of the industrial working class in the private sector, the process of union decline was characterised by markedly divergent trends in the private and public sectors from the 1970s. Unlike the old industrial working class, professional and quasiprofessionals in the public sector enjoyed a strengthening occupational position as employment in education and health grew strongly. Sheltered to a considerable degree from market competition, workers in these sectors also benefited from the fact that they were typically employed by a small number of employers (often state agencies); an employment pattern that facilitated union organising. The divergence of private/public-sector outcomes is most marked in Canada. In 2017, some 72 per cent of public sector workers are union members. By contrast, only 14.8 per cent of private-sector workers are unionised; an outcome that causes public sector unionists $(2,670,000)$ in Canada to outnumber their private-sector counterparts $(1,760,000)$ by a considerable margin. ${ }^{22}$ Clearly, the vaunted stability of Canadian union density owes comparatively little to "sustained institutional protections" and comparatively much to the benign attitude of all levels of government towards public sector unionism. The same pattern of private/public-sector divergence, albeit in a less marked form, is also evident in Australia and the USA. In 2016, the last year for which we have Australian figures on private and public sector density, 38.5 per cent of Australian public sector workers (totalling 606,500) were unionised compared to 9.3 per cent in the private sector $(941,100) .{ }^{23}$ Similarly, in the USA in 2017 some 34.4 per cent of public sector unionists $(7,220,000)$ were unionised compared to 6.3 per cent in the private-sector $(7,570,000){ }^{24}$

Self-evidently, the survival of unions as a significant industrial force in Australia, Canada and the USA would be impossible if

20. Bruce Western, "A Comparative Study of Working-Class Disorganization: Union Decline in Eighteen Advanced Capitalist Countries," American Sociological Review 60, no. 2 (1995): 12. At the time of writing, this work had 214 citations.

21. Gregor Gall, Richard Hurd and Adrian Wilkinson, "Labour Unionism and Neo-Liberalism," in The International Handbook of Labour Unions: Responses to Neo-Liberalism, ed. Gregor Gall, Richard Hurd and Adrian Wilkinson (London: Edward Elgar Publishing), 2.

22. Statistics Canada, "Union Status by Industry," 3.

23. ABS, Characteristics of Employment, Australia, August 2016, Table 18.1.

24. United States Bureau of Labor Statistics, "Economic News Release" 19 January 2018, Union Members Summary, accessed January 2020, archived at https://web. archive.org/web/20181223031830/https://www.bls.gov/news.release/union2.nr0.htm. 
governments - including those of pronounced "neoliberal" orientation were remorselessly hostile when it came to bargaining with their own employees. The uniformity of outcomes across markedly different jurisdictions indicated in Figure 3 is confirmed in Figures 4, 5 and 6, which record absolute membership in each statistical category for Australia in 2018 and for Canada and the USA in 2017. In presenting the figures, a few caveats need to be provided. In the USA, union membership for health and education only relate to private-sector employment. In this jurisdiction, most teachers and health workers are employed by local government. By contrast, Canadian figures combine fishery and forestry workers (significant areas of Canadian employment) with those for mining. US "IT" workers include those working in media and printed forms of news and current affairs. Canada includes "IT" with art and recreation, and wholesale trade with retail trade. Across all jurisdictions, the term "hospitality" is used in preference to "food and accommodation." Such caveats aside, the uniformity in patterns of comparative strength and weakness is clear. In each jurisdiction, membership is concentrated in government employment, health and education. Despite vaunted campaigns that have attracted significant research attention, ${ }^{25}$ unions in all three nations have virtually no active support amongst hospitality workers, density ranging from a high of 6.1 per cent in Canada to lows of 3.3 per cent and 2.9 per cent in Australia and the USA, respectively. One area of comparative Australian strength is in retail, where Australian density (12.72 per cent) is higher than either Canada (11.7 per cent) or the USA (4.5 per cent). Significantly, retail workers are fourth largest cohort in the ranks of Australia's unions, the 127,200 retail members easily outnumbering those in manufacturing $(98,200)$, transport $(110,700)$ and construction $(90,200){ }^{26}$

What explains the comparatively large cohort of retail workers in Australian union ranks, a success that underpins the considerable influence of Australia's largest union, the Shop, Distributive and Allied Employees' Association (SDA), within the Labor Party and the ACTU? The kindest explanation is the existence of a "social partnership" between the SDA and the large employers who dominate the retailing and fast food industries, in particular Coles, Woolworths, Yum Foods/KFC and McDonalds. The extent of these agreements, it should be noted, is more extensive than one would suppose in that large fast food employers such as McDonald's

25. See, for example, Charlotte A. B. Yates, “The Revival of Industrial Unions in Canada: The Extension and Adaptation of Industrial Union Practices to the New Economy," in Trades Unions in Renewal: A Comparative Study, ed. Peter Fairbrother and Charlotte A. B. Yates (London: Continuum, 2003), 221-43.

26. ABS, Characteristics of Employment, Australia, August 2018, Table 3.1; Statistics Canada, "Union Status by Industry," 2013-17, Table 14-10-0132-01; US Bureau of Labor Statistics, “Economic News Release," 19 January 2018, Table 3. 


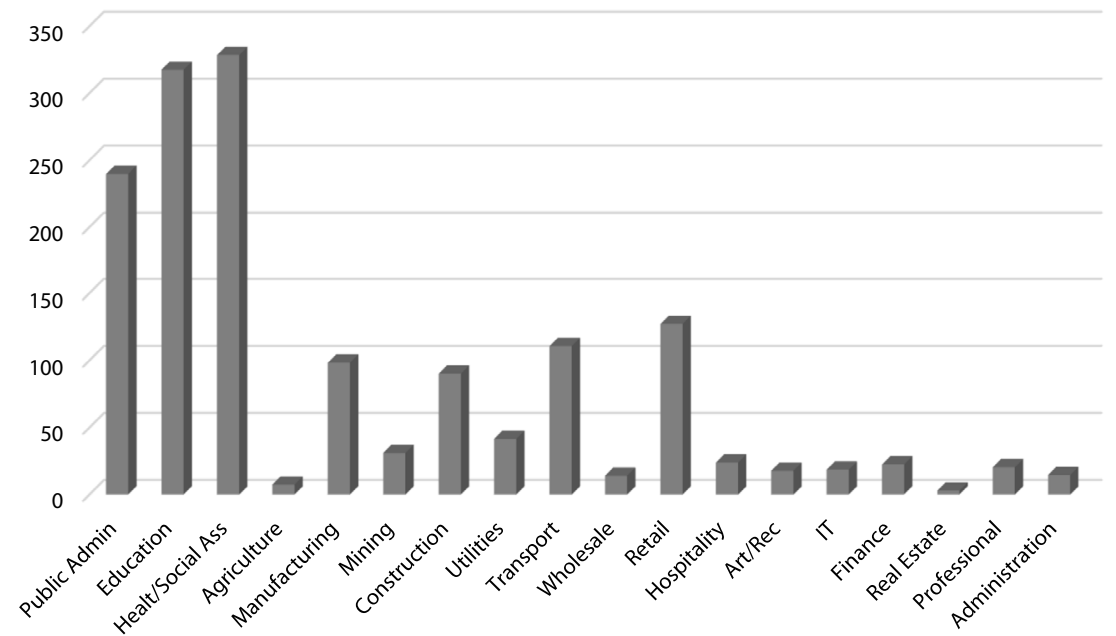

Figure 4: Australian Union Membership (in thousands) by Industry, 2018 ABS, Characteristics of Employment, August 2018, cat. 6333.0, Table 3.1

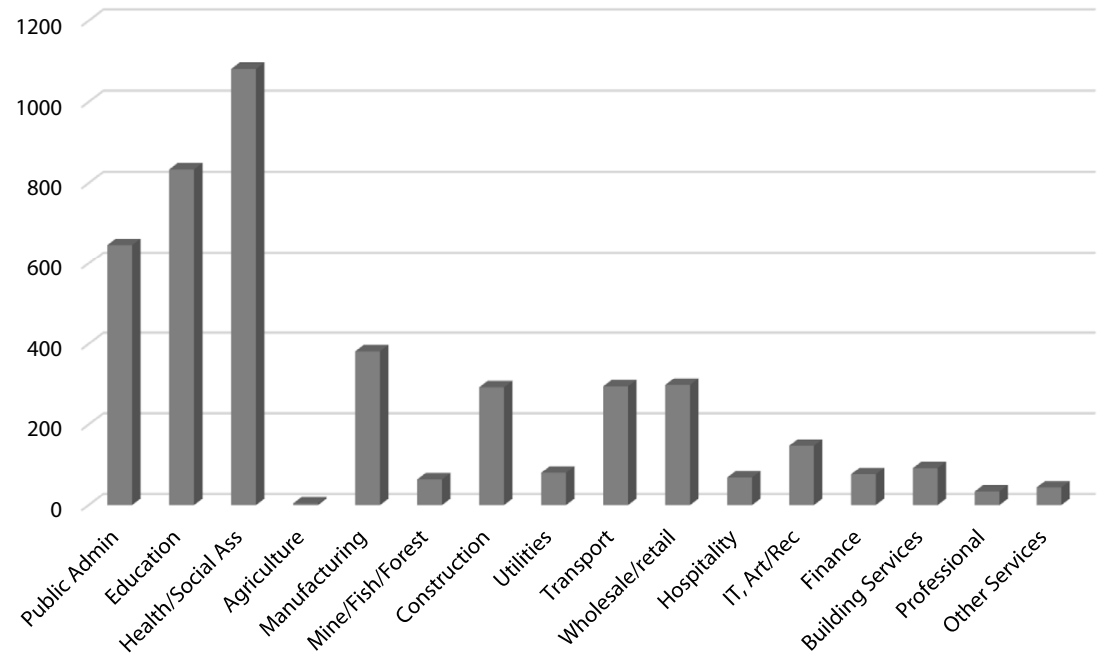

Figure 5: (anadian Union Membership (in thousands) by Industry, 2017

Statistics Canada, "Union Status by Industry," 2013-17, Table 14-10-0132-01 


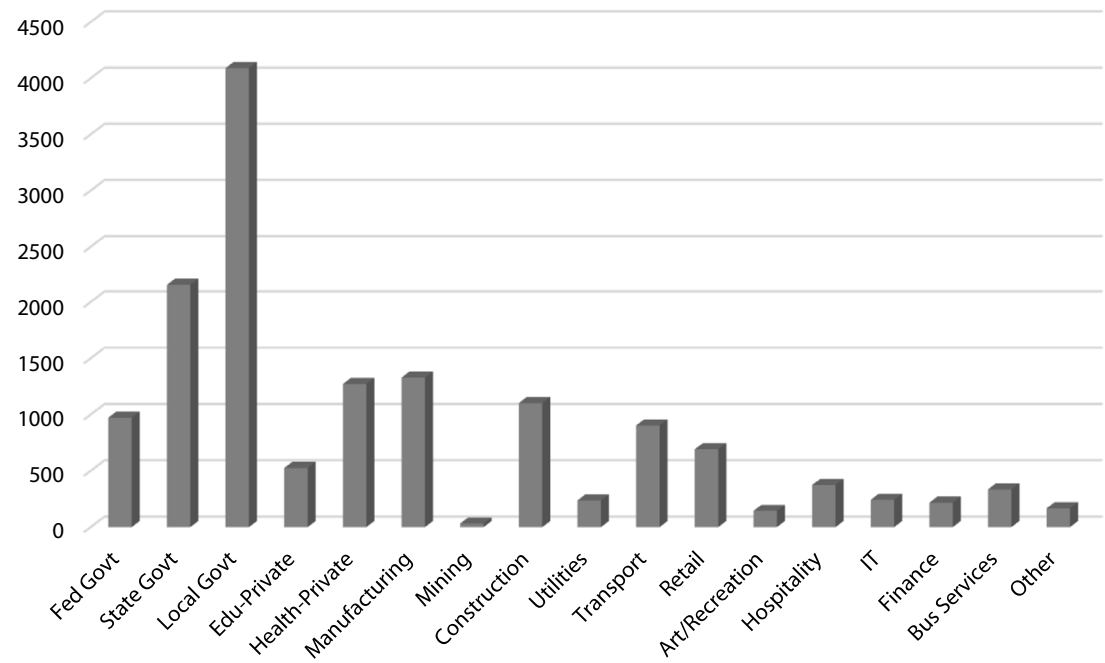

Figure 6: United States Union Membership (in thousands) by Industry, 2017

United States Bureau of Labor Statistics, "Economic News Release," 19 January 2018, Table 3: Union Affiliation of Employed Wage and Salary Earners by Occupation and Industry, 2016-17

and Yum Foods (KFC) act as "bargaining agents" on behalf of their franchisees, the franchisees' inclusion invariably found in an annexure to the registered agreement. A less kindly explanation for the SDA's extraordinary success is proposed by the rival (and unregistered) Retail and Fast Food Workers' Union (RFFWU), whose website states that the SDA negotiates agreements that "undercut the minimum terms and conditions of workers" in exchange for provisions whereby employers assist the SDA in recruiting members. ${ }^{27}$ Certainly, one does not need to look far to find evidence for such allegations. Under the Dan Murphy's Agreement 2012, s 14, for example, the SDA agreed to provisions that effectively eliminated penalty provisions during the hours that the liquor retailer not only traded but stocked; this in nominal return for a $\$ 2.44$ increase in the base rate from July 2014 (\$21.41 rather than \$18.97) for a level 2 employee. Consequently, Dan Murphy workers who worked an eight-hour day shift during the week were $\$ 19.52$ better off. If, however, they worked the same hours on Saturday the elimination of penalties meant that they were $\$ 28.33$ worse off than if

27. "SDA Facts," Retail and Fast Food Workers Union, accessed January 2020, www. raffwu.org.au/sda_facts. Despite its appellation, this organisation is not a registered union and is best regarded as a social activist grouping. 
they were engaged under the award. If they worked the same hours on Sunday, they were out of pocket by $\$ 132.24 .^{28}$

The nature of the "social partnership" between the SDA and employers is even more apparent in the agreement that currently applies to McDonald's workers - the McDonalds' Australia Enterprise Agreement 2013 - where the only penalty rate that applies is a 10 per cent loading between the hours of 1am and 5am. Accordingly, if a 21-year-old employed as a level 2 worker (the most common designation) worked an eight-hour shift on a Saturday under the union-negotiated agreement they would have received $\$ 172.88$ in June 2018. The same worker, if engaged under the Fast Food Industry Award, would have received \$212.90; an outcome that leaves those on "union conditions" $\$ 40.02$ worse off. In return for such benefits, under s 43 of the agreement, the employer agreed to invite SDA officials to inductions and "crew meetings" at each store. ${ }^{29}$ Similarly, under the KFC Team Members Enterprise Agreement (Queensland and Tweed Heads 2014-17) the SDA agreed to a "buy-out" of penalty provisions in return for a 9 per cent increase in base rates. Consequently, in June 2018 a KFC worker who undertook an eight-hour shift was $\$ 28.33$ worse off on Saturdays, and $\$ 72.31$ worse off on Sundays, than if they had been employed under the award. Once more the SDA gained a suite of concessions relating to membership recruitment; concessions embodied in s 15 of the agreement under the heading, "Union Related Matters and Union Encouragement." 30 Across the last decade, provisions leaving workers out of pocket when working at night or on weekend works, were found in agreements covering Coles, Woolworths, Dominos, Bunnings, BWS, Kmart and Big W, among others. It should also be noted that recent challenges to the SDA's fast food agreements by the unregistered RTFWU have in many ways left unionism and workers in an even more precarious situation than previously. Yes, it is true, that campaigns by the RFFWU caused McDonalds in May 2019 to declare, on behalf of its own stores and those of its franchisees, that it would pay "weekend penalty" rates on a voluntary basis. ${ }^{31}$ How many

28. Dan Murphy's Agreement 2012, FWC, accessed January 2020, www.fwc.gov.au/ documents/documents/agreements/fwa/ae899725.pdf. In 2014, a 100 per cent penalty applied to Sunday work under the award.

29. Base rates as of June 2018 were $\$ 21.29$ under the award and \$21.61 under the agreement. Award workers were entitled to a 25 per cent penalty that was foregone under the agreement. McDonalds' Australia Enterprise Agreement 2013, FWC, available on the SDA website, accessed January 2020, www.sda.org.au/resources/ enterprise-agreements/.

30. KFC Team Members Enterprise Agreement: Queensland and Tweed Heads (NSW) 2014-2017, FWC, accessed January 2020, www.fwc.gov.au/document/agreement/ AE410007.

31. Ben Schneiders and Royce Millar, “Huge Wage Boost and Penalty Win for 100,000 
franchisees have opted to do so is unknown. Nevertheless, as of December 2019, the McDonalds' Australia Enterprise Agreement 2013 remained in force. This situation prevails despite 50,000 McDonald's workers voting overwhelming in favour of a new SDA-negotiated enterprise agreement. ${ }^{32}$ However, in the face of objections from the RFTWU, in September 2019, McDonald's decided to withdraw from the registration of the agreement with the Fair Work Commission (FWC). ${ }^{33}$ If McDonald's also decides to seek the withdrawal of the 2013 Agreement, this leaves McDonald's workers without any agreement whatsoever. In consequence, the many SDA delegates and activists employed by McDonald's and its franchisees would be left without the formal recognition, rights and protections they currently enjoy under the McDonalds' Australia Enterprise Agreement 2013.

While it would be tempting to think that the agreements discussed above are exceptions to the rule in retailing and fast food, the tendency of agreements to leave workers worse off (at least in regard to night and weekend work) has in fact been the norm in these sectors. It is the foundation upon which SDA and (to a lesser degree) United Voice membership is built. As a full bench of the FWC noted in August 2017 in terminating the agreements negotiated between Coles and the SDA in both 2011 and 2014, the fact that workers have been worse off under these arrangements is easily discerned. It was, the FWC observed, something that "Coles" (and presumably the SDA and the ACTU) "ought reasonably to have known." 34

The fact that many, if not most, workers in retail and hospitality have been financially worse off under union agreements than if they were paid under the award is not to condemn the ACTU or the SDA. They have faced choices offered by the devil. Enter into "social partnerships" with employers, and trade-off penalties for a unionised workplace, or face being locked out of the sector altogether. While not condemning, as labour historians we nevertheless need to recognise that the considerable union membership in retail is built on this "social partnership." Without the SDA's 230,000

McDonald's Workers," Sydney Morning Herald, 10 May 2019, accessed January 2020, www.smh.com.au/business/workplace/huge-wage-boost-and-penalty-rate-win-for100-000-mcdonald-s-workers-20190510-p51lyq.html.

32. "Media Release: New McDonald's Agreement Approved by Workers," 4 June 2019, SDA, accessed January 2020, www.sda.org.au/media-release-newmcdonalds-agreement-approved-by-workers/.

33. "Media Statement: McDonald's Enterprise Agreement Withdrawal Disappointing," 30 September 2019, SDA, www.sda.org.au/media-statement-mcdonalds-enterpriseagreement-withdrawal-disappointing/.

34. Decision: Application for Termination of the Coles and B-Lo Enterprise Agreement 2011, FWC, 17 August 2017, 2, accessed January 2020, www.fwc.gov.au/documents/sites/ coles-agreement-case/decision-2017fwcfb4295.pdf. 


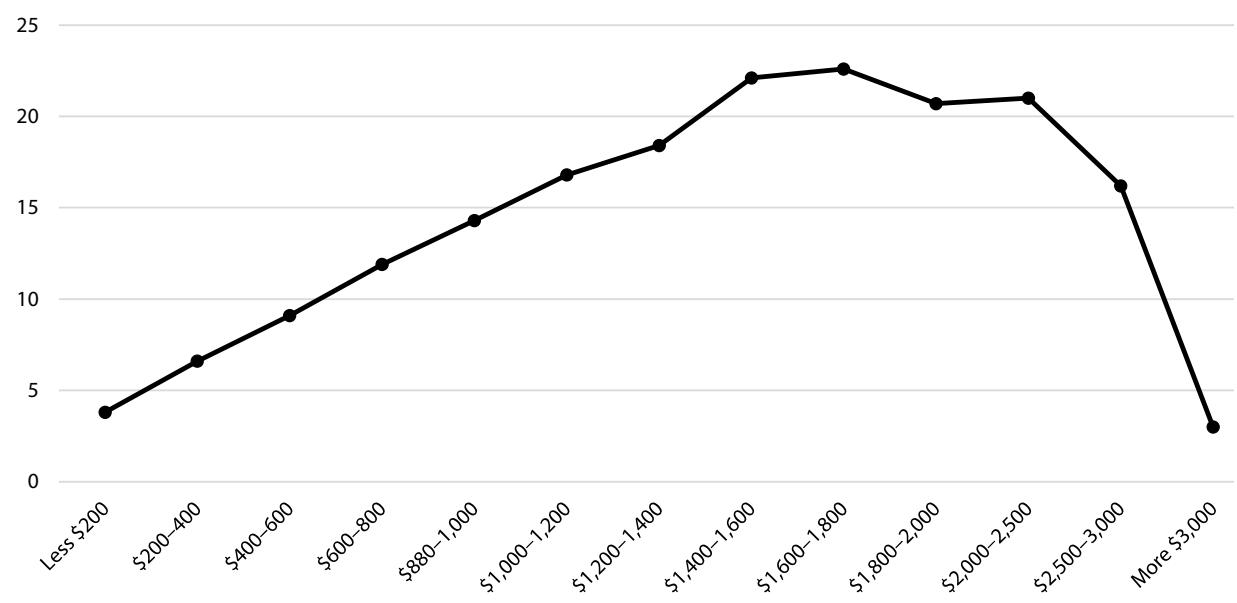

Figure 7: Union Density According to Wage Bands, 2016

ABS, Characteristics of Employment, Australia, August 2016, cat. 6333.0

members ${ }^{35}$ most recruited with employer assistance, the Australian union movement would have little organised presence in the low-pay service sector. The SDA's low-paid membership is, however, something of an aberration in today's union movement. Rather than being dominated by working-class battlers, unions today are increasingly dominated by society's better-paid. As Figure 7 indicates, propensity to join a union increases with wealth. Of those earning \$1,600-\$1,800 per week in August 2016, 22.6 per cent were unionised. Among those paid \$2,500-\$3,000 per week - the second highest wage cohort that the ABS reports - 16.2 per cent were union members. By contrast, among those earning $\$ 600-\$ 800$ per week only 11.9 per cent were union members. Among the ABS's worst paid cohort - those earning less than $\$ 200$ per week - only 3.8 per cent were union members. ${ }^{36}$

The fact that propensity to join is now correlated with wealth is reflected in the higher wages received by unionists when compared to non-unionists. As Figure 8 indicates, this gap increased significantly between 2016 and 2018, the gap amounting to 17.5 per cent in 2016 and 21.1 per cent in 2018. ${ }^{37}$ Now, historically, a union "wage premium" has been attributed to union bargaining. ${ }^{38}$ However, there are reasons to doubt that the current (large)

35. "About the SDA," SDA Tasmania, accessed January 2020, www.sdatas.asn.au/ about-the-sda/.

36. ABS, Characteristics of Employment, Australia, August 2016, Table 18 and Table 19.

37. Ibid., ABS, Characteristics of Employment, Australia, August 2018, Table 3.1.

38. See, for example, David Peetz, Brave New Workplaces: How Individual Contracts Are Changing Our Jobs (Sydney: Allen \& Unwin, 2006), 102. 


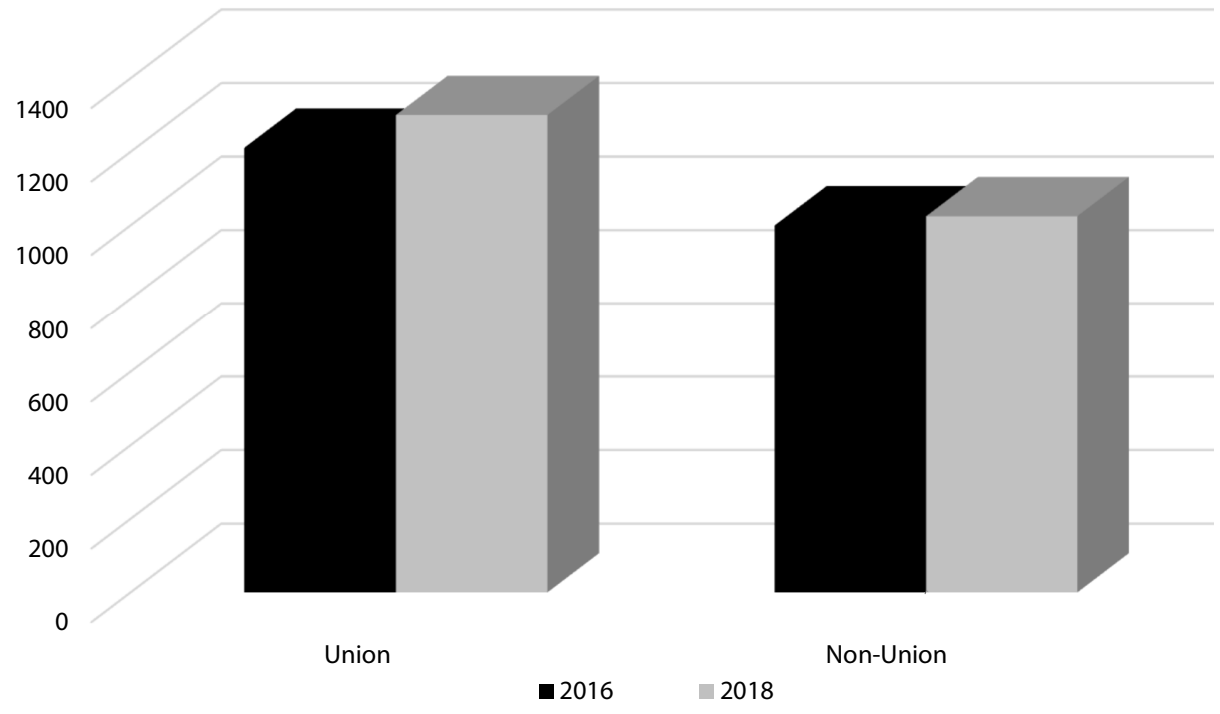

Figure 8: Median Wage, Union and Non-Union, 2016-18

ABS, Characteristics of Employment, Australia, August 2016, cat. 6333.0

wage gap is attributable to union bargaining per se. First, even when workers (most particularly in the private sector) do belong to a union there is a very good chance that they will not be employed under an enterprise agreement. Conversely, where there is an agreement, workers can enjoy its benefit without need for a union membership ticket; a phenomenon referred to as "free-riding." Collectively, these outcomes suggest that rather than it being the case that union membership causes higher wages, it is the case that union membership is caused in many cases by the prior possession of a comparatively high wage. Accordingly, the decision not to join by low wage earners is, one suspects, informed in large part by the belief that union fees are an unaffordable luxury. Union membership can thus be seen as something akin to private medical insurance: a luxury enjoyed by society's more prosperous to protect them against unforeseen adverse employment outcomes. Similarly, the growing wage gap between unionists and non-unionists can be attributed to the shrinking number of low-paid workers who opt to pay membership dues. Admittedly, there is a growing argument that a key causal factor in union decline is the practice of so-called "free-riding," where workers attain the benefits of union bargaining without paying for them..$^{39}$ Even if, however, Australia introduced a Canadian-type

39. See, for example, David Peetz, "Submission to the Productivity Commission Inquiry into the Workplace Relations Framework, 2016," 20, Commonwealth of 
system whereby all those who are covered by an agreement are required to pay dues - an unlikely outcome given the emphasis on "freedom of choice" in both our industrial relations laws and in the wider culture - it is unlikely that such changes would significantly increase the number of low-paid union members. In Canada, for example, the percentage of hospitality workers with a union ticket is, as we have previously noted, only 6.1 per cent; an outcome only marginally superior to Australia (3.3 per cent). Instead, anti-"free-rider" provisions would most likely have the greatest effect in high-pay areas already characterised by significant union membership (public administration, education and health).

In noting the comparative absence of society's poorer members in the ranks of today's unions - whether in Australia, Canada or the USA - it is not being suggested that the ACTU or unions such as the SDA are not mindful of society's disadvantaged. Similarly, this article is not casting aspersions as to the genuineness of the ACTU's current demand for the reinstatement of "a living wage." 40 Rather, what is being suggested is that not only is it a fact that society's poorest are currently under-represented in the ranks of Australia's unions, it is also the case that to merely "change the rules," as the ACTU is recommending, will at best only have an effect on the margins. For if we look to a country such as Canada - whose industrial relations laws are rated more union-friendly by the ICTU ${ }^{41}$ - private-sector union membership (14.7 per cent) is not significantly higher than Australia (9.3 per cent). Nor, as we have previously highlighted, have different laws produced any significant difference in the structural composition of Canadian union membership when compared to either Australia or the USA. In each instance, union membership is increasingly composed of those in the public-sector, and in quasi-public sector areas such as education and health; areas where large concentrations of workers amenable to union organising are spared the full effects of the market forces to which most private-sector workers are exposed.

Australia Productivity Commission, accessed January 2020, www.pc.gov.au/_ data/assets/pdf_file/0007/187945/sub0133-workplace-relations.pdf; Sally McManus, "Speech to AIRAANZ, February 2018," Australian Council of Trade Unions, accessed January 2020, www.actu.org.au/actu-media/speeches-and-opinion/ sally-mcmanus-speech-to-airaanz-february-2018.

40. ACTU, “Submission to the Annual Wage Review 2018," 9, FWC, accessed January 2020, www.actu.org.au/actu-media/speeches-and-opinion/sally-mcmanus-speech-toairaanz-february-2018.

41. ITUC Global Rights Index 2018, 2. Under the ITUC rating, Canada is declared category 2 (second best) and Australia a mid-level category 3 rating. 


\section{Failures of Explanation}

In 1997, Michael Costa, then the assistant secretary of the New South Wales Trades and Labour Council, observed that, "the ACTU has developed a habit of looking for quick fixes to complex problems." What characterises this habit, Costa continued, was the tendency to continually latch on to overseas "revitalisation" strategies while ignoring "the subtle, but crucial, differences of history, culture and economic structure" that differentiated Australia from the nations inspiring the strategy of the moment. ${ }^{42}$ To a lesser degree, similar comments can made about the Australian labour history and industrial relations scholarship that has attempted to explain union decline over the last 30 years; a period that has seen explanations once embraced with fervour almost totally disappear from the lexicon. This is most obviously the case with regards the view, central to the ACTU's revitalisation strategy of the 1980s and early 1990s, that productivity-based bargaining would cement the role of unions in a more dynamic economy. For instance, in Peetz and Yu's recent report on collective bargaining - completed for the FWC in 2017 - the term "productivity" does not appear once in the report's 62 pages. ${ }^{43}$ Similarly, in the Journal of Industrial Relations 2018 report into the state of unions and collective bargaining in Australia, the word "productivity" appears but twice. On both occasions, this related to the "Productivity Commission": not "productivity" per se.44 It is also fair to say that, a quarter of a century on from the ACTU's adoption of the "Organising Model," the once enthusiastic research interest in this domain has also quietly abated. The attribution of union decline to "structural changes" in the economy, a line of argument never pursued with consistent vigour - Peetz recording in 1998 that the supposed "acceleration of the decline in union density" that occurred during the 1990s "cannot even be partly explained by structural change" - has also attracted little recent research interest..$^{45}$ By contrast, the

42. Michael Costa, "Union Reform, Union Strategy and the Third Wave: Introduction," in Reforming Australia's Unions, ed. Michael Costa and Mark Hearn (Sydney: Federation Press, 1997), 22.

43. David Peetz and Serena Yu, Research Report 4 / 2017: Explaining Recent Trends in Collective Bargaining (Canberra: Commonwealth of Australia, 2017), available on the FWC website, accessed January 2020, www.fwc.gov.au/awards-agreements/ minimum-wages-conditions/annual-wage-reviews/annual-wage-review-2016-17/ research; David Peetz, Unions in a Contrary World (Melbourne: Cambridge University Press, 1998), 14.

44. Peter Gahan, Andreas Pekarek and Daniel Nicholson, "Unions and Collective Bargaining in Australia in 2017," Journal of Industrial Relations 60, no. 3 (2018): 337-57.

45. Peetz, Unions in a Contrary World, 82. The major study that has explained union decline through reference to profound sociological changes is Bradley Bowden, 
tendency to explain union decline through reference to "neoliberalism" is more pronounced; a tendency evident in terms of both research focus and ACTU pronouncement. In exploring the explanations for union decline ascertaining what is of value in past explanations as well as the factors behind their being superseded - this final section of this article suggests that explanations have suffered from two, interrelated problems. First, explanations have suffered from a lack of balance, whereby sweeping assertion fails to accord with observed outcome. The second failing is a tendency to be captivated by short-term influences (laws, union campaigns, etc), thereby paying insufficient heed to long-term structural changes in the economy and wider society. Thus, where "structural changes" have been considered - as by both Peetz and Mark Wooden in the late 1990s and early 2000s - the identified effects have typically been understated. The reason for this is that timeframes chosen have been typically narrow; both Peetz and Wooden measuring "structural change" from 1976, a date that appears to have been primarily chosen so as to accord with particular datasets. ${ }^{46}$ A consequence of this is that there has been little evident appreciation of the profound structural shifts that have occurred in the occupational composition of union membership; shifts that will make it difficult for unions to rebuild their once strong private-sector base. In the ensuing section, we explore each of these failings.

As Australian union decline recommenced after the hiatus of the 1970s the initial response, both in terms of ACTU policy and theoretical explanation, revolved around "productivity-based bargaining." The centrality of this concept was emphasised in October 1991, when the Australian Industrial Relations Commission made "enterprise-bargaining" the primary mechanism for wage increases, declaring that wage increases "ought" to be "commensurate with employees' contribution to enterprise efficiency and productivity." 47 In part, this shift was driven by so-called "New Right" employer organisations; their demand exemplified in the Business Council of Australia's Enterprise-Based Bargaining Units: A Better Way of Working.48 Arguably more influential were the experiences of the ACTU and the then dominant metal unions, traumatised by the loss of 200,000 manufacturing jobs between 1974 and 1984; losses that they (correctly) feared heralded a permanent structural shift in Australian employment. For the ACTU,

“The Rise and Decline of Australian Unionism, 1820-2010," Labour History, no. 100 (May 2011): 51-82.

46. Peetz, Unions in a Contrary World, ch. 4; Mark Wooden "Union Amalgamations and the Decline in Union Density," Journal of Industrial Relations 41, no. 1 (1999): 35-52.

47. Australian Industrial Relations Commission, National Wage Case, 30 October 1991, Print K0300, 4.

48. Business Council of Australia, Enterprise-Based Bargaining Units: A Better Way of Working (Melbourne: Business Council of Australia, 1987). 
the solution to such problems required the fostering of a "production consciousness" among both workers and employers; a consciousness best forged through Scandinavian-style co-operative relationships at the enterprise level. ${ }^{49}$ Supportive of the ACTU's "production consciousness" were research streams that drew inspiration from the USA. One of these streams articulated the concept of "strategic unionism," whereby it was argued that unions could counter deunionisation by helping to create "high-productivity/high-wage" workplaces; ${ }^{50}$ a model which Peetz adapted in 1998 in his so-called "change-response model," which held that, "[w]hatever changes occur in the [industrial relations] system, unions are in a position to respond." 51 A second stream of influential America-initiated research suggested that unions could become central to new, flexible work systems by fostering both "employee voice" and "joint decision making" in ways that raised productivity and wages..$^{52}$ Thus we were informed that workers "who perceived unions as co-operating with management were substantially more satisfied with their union";53 that "the future" of unions "must be based not on a return to centralised wage fixing ... but on decentralised bargaining";; that "the demise of compulsory unionism" should be embraced as part of a "paradigm shift in Australian union membership." 55 Admittedly, there were sceptics who doubted the restorative effect of workplace bargaining. Some doubted that unionised firms could ever be more cost-effective (as against productive) than non-union rivals. ${ }^{56}$ Others feared that demands for "efficiencies" would cause employers to abandon their productivity-focused dalliance with unions. ${ }^{57}$ Despite such scepticism, the embrace of produc-

49. ACTU/TDC, Australia Reconstructed, chs 5 and 6.

50. Thomas A. Kochan, Harry C. Katz and Robert B. McKersie, The Transformation of American Industrial Relations, 2nd ed. (New York: Basic Books, 1988), ix-x, 241.

51. Peetz, Unions in a Contrary World, 2, 184.

52. Richard B. Freeman, "The Future of Unions in Decentralized Collective Bargaining Systems: US and UK Unionism in an Era of Crisis," British Journal of Industrial Relations 33, no. 4 (1995): 524.

53. Peetz, "Unions, Conflict and the Dilemma of Cooperation," 560.

54. Michael Alexander, Roy Green and Andrew Wilson, "Delegate Structures and Strategic Unionism: Analysis of Factors in Union Resilience," Journal of Industrial Relations 40, no. 4 (1998): 663.

55. David Peetz, "The Paradigm Shift in Australian Union Membership: A Tale of Compulsory Unionism," in Current Research in Industrial Relations: Proceedings of the 11th AIRAANZ Conference, ed. Tom Bramble (Brisbane: Association of Industrial Relations Academics of Australia and New Zealand, 1997), 300.

56. See, in particular, Barry T. Hirsch and John T. Addison, The Economic Analysis of Trade Unions (Boston, MA: Allen \& Unwin, 1986).

57. Bradley Bowden, "A Collective Catastrophe: Productivity Maximisation and Workplace Bargaining in the Australian Coal Industry," Journal of Industrial Relations 42, no. 3 (2000): 380, 365; Joe Isaacs, "Australian Labour Market Issues: An Historical Perspective," Journal of Industrial Relations 40, no. 4 (1998): 690-715. 
tivity-based bargaining permanently altered not only union policy but also societal expectations as to when and how improvements in wages occurred.

Given the favour with which productivity-based bargaining was once regarded its disappearance from the union revitalisation literature is quite extraordinary. As noted above, major reports into "collective bargaining," such as that by Peetz and Yu, avoid mention of the term. Where it is discussed its pursuit, most notably by bodies such as the Productivity Commission, is typically seen as antipathetic to "imperatives such as fairness and voice." ${ }^{58}$ In part, the pronounced shift that has occurred in relation to productivity-based bargaining - and its role in any programme of union revival - is indicative of the lack of balance and perspective that has characterised the whole discussion of union revitalisation more generally. Marked by a considerable naivety in its original formulations which constantly saw productivity, unionisation and employer co-operation advancing hand-in-hand - it was perhaps inevitable that an eventual reaction against the effects of productivity bargaining would be associated with dramatic changes in opinion. Thus Peetz, a previous enthusiast for productivity-based bargaining, recorded in 2006 that "there is no consistent relationship between unionism and productivity" and that "productivity is not what corporations seek - it is profitability that they seek." ${ }^{59}$ Similarly, the ACTU's McManus declares that "productivity goes up but wages do not ... Enterprise bargaining is broken." 60 The changed attitudes towards productivity, which have arguably swung from one extreme to the other, are unfortunate. Across all advanced economies, annual increases in productivity between 2008 and 2016 averaged a mere 0.8 per cent; a level only half that of the previous eight years. This slowdown in global productivity, which is central to the stagnation in real wages that effects virtually every advanced economy, is now seemingly entrenched in Australia where according to the FWC's annual wage review - productivity fell by 1 per cent in 2017.61 Without a reversal in such trends, any sustained recovery in either real wages or union membership is unlikely.

As time progressed and union decline gathered pace many of the enthusiasts for productivity bargaining joined the exponents of the "Organising Model"; a cure for union ills that, like productivity bargaining, emphasised workplace activism rather than institutional settings. Unlike the previous explanation, however, the "Organising Model" identified internal

58. Chris F. Wright, “Australian Industrial Relations in 2015," Journal of Industrial Relations 58, no. 3 (2016): 298.

59. Peetz, Brave New Workplaces, 69, 74. Emphasis in the original.

60. McManus, "Change the Rules," 1, 4.

61. FWC, Statistical Report: Annual Wage Review 2017-18, 25 May 2018, available on the FWC website, accessed January 2020, www.fwc.gov.au/awards-agreements/ minimum-wages-conditions/annual-wage-reviews/annual-wage-review-2017-18-2. 
union failings as the main causal factor in union decline. Accordingly, we were now advised that that a self-interested focus on existing membership had left "whole sectors of the economy" untouched by union activity, ${ }^{62}$ that "revitalization of unionism" had to occur "at the workplace,"63 that the more vigorous pursuit of the "Organising Model" from 1999 under Combet represented a fundamental turning point. ${ }^{64}$ Constantly, advocates of the "Organising Model" found proof of the success of this strategy in a supposed halt to union decline, it being recorded in 2006 that, "The tide that had seemed to be swamping unions had somehow been held back ... By 2004, in trend terms, union membership had stabilised."65 Union revival was even predicted in the Pilbara, where Bradon Ellem wrote in 2003 that, "In the Pilbara's iron ore sites, the organising strategy ... has been seized upon with particular enthusiasm." 66 Such pronouncements proved exercises in wishful thinking. In the Pilbara, as elsewhere, any revival that did occur was limited and short-lived, Ellem's latest book recording of the Pilbara that "in few places have unions risen so high and fallen so low." ${ }^{67}$

One of the consequences of the belief that unions could prove masters of their own fate (productivity bargaining, organising etc.) was that it required the downplaying of "structural changes" in the economy. This is evident, as we have previously noted, in the work of both Peetz and Wooden, each of whom has undeniable expertise in the field of labour economics. Significantly, each chose to start their analysis of "structural change" at 1976, a date that is easily justified on methodological grounds in that 1976 marks the beginning of a consistent new ABS labour force survey of union membership (ABS, cat. 6325.0), but that automatically rules out a longer historical analysis.68

62. Kate Bronfrenbrenner, "The American Labour Movement and the Resurgence of Union Organizing," in Trade Unions in Renewal: A Comparative Study, ed. Peter Fairbrother and Charlotte Yates (London: Continuum, 2003), 39.

63. David Peetz, Barbara Pocock and Chris Houghton, "Organisers' Roles Transformed? Australian Union Organizers and Changing Union Strategy," Journal of Industrial Relations 49, no. 2 (2007): 152.

64. Peetz, Brave New Workplaces, 163.

65. Ibid.; also see Ruth Barton, David Snell and Peter Fairbrother, "Unions in the Twenty-First Century and Beyond" (paper presented at Unions in the Twenty-First Century and Beyond Conference, Melbourne, 17-19 November 2008), 8.

66. Bradon Ellem, "New Unionism and the Old Economy: Community and Collectivism in the Pilbara's Mining Towns," Journal of Industrial Relations 45, no. 4 (2003): 424.

67. Bradon Ellem, The Pilbara: From the Deserts Profits Come (Perth: University of Western Australia Publishing, 2017), 4. The only Australian work written in this period that predicted no benefit from the "Organising Model" was, Bradley Bowden, "The Organising Model in Australia: A Reassessment," Labour E Industry 20, no. 2 (2009): 138-58.

68. Peetz, Unions in a Contrary World, ch. 4; Peetz, Brave New Workplaces, 31, 54; Wooden "Union Amalgamations and the Decline in Union Density," 35-52. Wooden primarily compares 1989/90 and 1995. 
Second, Peetz, in particular, also chose to define "structural change" in narrow terms. Rather than giving primacy to changes in class composition or employment by sector (manufacturing, mining, etc), Peetz focused on simply measuring changes in employment in "low density" areas when compared to "high density" areas; an approach that reduced "structural change" to easily calculable mathematics. Accordingly, the profound occupational change that was occurring in both Australian society and in union membership is relegated to secondary status, Peetz declaring that "occupational differences" were "less important" than "sectoral differences," most notably between the private sector (comparatively low density) and the public sector (high density). ${ }^{69}$ Similarly, the idea that Australia was experiencing a class transformation was dismissed, Peetz supposing that, "[w]hile blue-collar jobs have sharply declined, the notion of 'working class' has not."70 In total, Peetz estimated that "structural" factors accounted for only 22 per cent of union decline between 1982 and 1992, and only 2 per cent of the decline between 1992 and 1997.71 Operating from similar premises, Wooden also concluded that there was "weak support" for the idea that occupational changes were behind falling union density.72 What counted from these perspectives was not sociological change but rather the strategies unions chose in responding to such changes - and the institutional settings that either hindered or helped those responses. ${ }^{73}$

Given the emphasis that union revitalisation strategies increasingly place on institutional settings, it is useful to consider the utility of Western's much-cited theoretical framework in this domain. Arguing that "institutions matter," Western concluded that union decline across "advanced capitalist countries" was associated with an increase in decentralised bargaining, less favourable legal frameworks and more open markets. Western also concluded that "unions' organizing capacity" falls "when leftist parties lost office" or when incumbent social democratic administrations prove "less supportive of union goals." ${ }^{\prime 4}$ Superficially attractive, Western's association of union strength with embedded "institutions" suffers two problems. First, at a conceptual level it assumes that union decline is caused by political and institutional changes, when it is arguable that these changes were an effect of union decline (ie social democratic parties are less oriented towards unions due to the diminution of union membership). That this possibility was not considered by Western is evident in his calculation of

69. Peetz, Unions in a Contrary World, 72.

70. Peetz, Brave New Workplaces, 31.

71. Peetz, Unions in a Contrary World, 70.

72. Wooden, "Union Amalgamations and the Decline in Union Density," 49.

73. See, in particular, Peetz, Unions in a Contrary World, 184.

74. Western, "Comparative Study of Working-Class Disorganization," 187. 
union decline "from the late 1970s," even though in both Australia and the USA the peak year for union density was $1948 .^{75}$ The second problem with Western's framework is the implication that, where institutional factors favour unions in one country, we can make a generalisation that is applicable elsewhere. An example of this is found in the institutional factors that support union density in Scandinavia (most particularly Denmark and Sweden), namely the so-called "Ghent-system," whereby unions administer the principal unemployment insurance system. That reliance on the "Ghent system" makes the union beneficiaries vulnerable to membership collapse is indicated by Swedish events between 2006 and 2008, when an increase in insurance fund membership fees caused national membership to fall by 6 per cent. ${ }^{76}$ That the Ghent system, and the high level of unionisation that it sustains, is transferable to other societies is an absurdity that does not bear consideration.

The lack of balance and perspective that characterises discussion of "institutional settings" is most evident in the association of Australian union decline with conservative governments "bent on their destruction."77 It is no doubt true that the Liberal-National coalition has little affection for unions, and their laws in recent decades have reflected this. But to link intent with outcome, and to assume correlation is causation, is a different matter. No doubt some, if not most, of the steep fall in union membership that occurred between 2005 and 2007, during which period unions shed 215,000 members, was due to the Coalition government's WorkChoices legislation. It would be foolhardy, however, to suggest that all of the membership lost was due to this cause. There were for example countervailing factors such as the popular response to the ACTU's call for legislative repeal. If the loss in union membership in 2005-07 was solely due to hostile laws we would also expect a recovery when the laws were repealed. This never eventuated. Moreover, the loss incurred under WorkChoices were less than the 225,400 members lost under Labor between 1992 and $1994 .{ }^{78}$ Certainly, if we look at the longer historical record it is difficult to distinguish a significant difference in the rate of union decline during the 1986 to 2007 period, or the subsequent 2007 to 2018 period, that we can clearly attribute to political incumbency. Another factually unsound explanation is the assertion that unions have suffered

75. Ibid., 180.

76. Anders Kjellberg and Christian Lyhne Ibsen, "Attacks on Union Organizing: Reversible and Irreversible Changes to the Ghent-Systems in Sweden and Demark," Lund University Research Portal, accessed January 2020, https://portal.research. lu.se/portal/en/publications/attacks-on-union-organizing(f4a5bbdb-23b2-49a7-b6f6d47427825de9).html.

77. Peetz and Bailey, "Dancing Alone," 531.

78. Union membership fell from 2,508,800 to 2,283,400 between 1992 and 1994, and from 1,911,900 to 1,696,400 between 2005 and 2007 . 


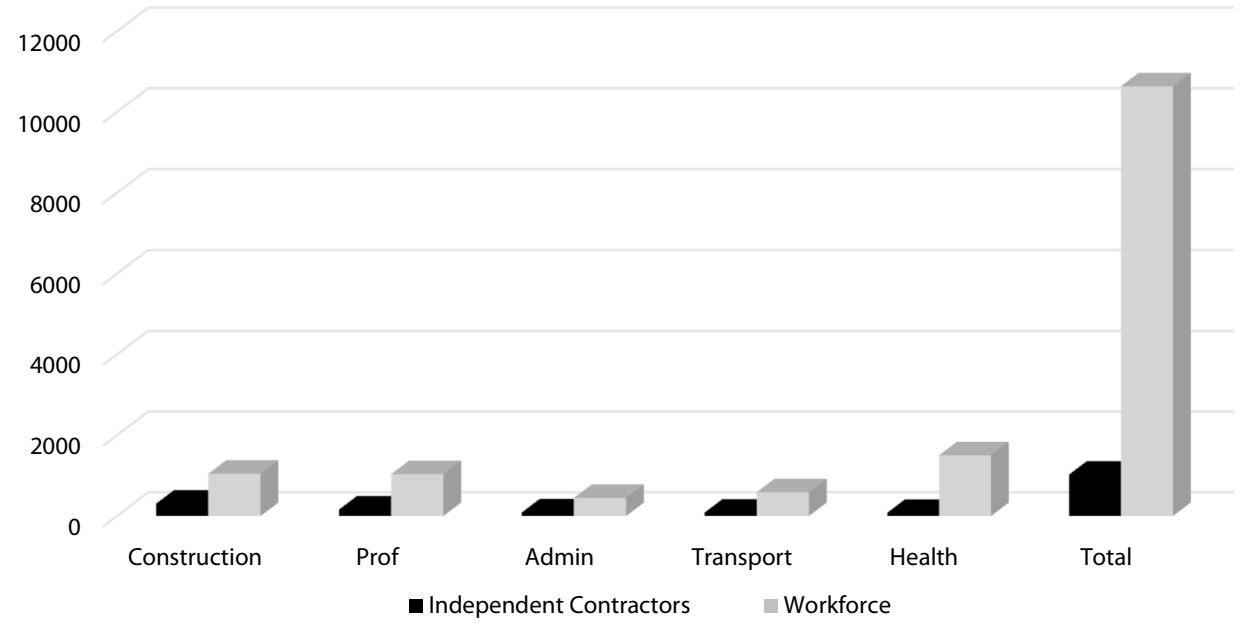

Figure 9: Independent Contractors: Workforce Shares, 2016

ABS, Characteristics of Employment, Australia, August 2016, cat. 6333.0, Table 16.1

greatly from a fostering of independent contracting in lieu of traditional employer-employee relationships. ${ }^{79}$ For, according to the ABS, independent contractors represented only 9.88 per cent of the workforce in 2016. As Figure 9 indicates, the largest cohort was in construction. Even here they represented only 29.7 per cent of the total. Elsewhere, the most numerous group $(162,400)$ was found in professional and scientific services. The great bulk of these, one imagines, would be consultants - a group not normally associated with exploitation. In health, as well, the large cohort of contractors $(81,900)$ would in large part comprise consulting medical specialists, such as my daughter - another group that few would regard as victims of exploitation. ${ }^{80}$ The recent emphasis on the so-called "gig" economy as a significant factor is also misplaced. Even if we assume that 10 per cent of workers in "transport, postal and warehouse," and 50 per cent of workers in "art and recreation," are in the "gig" economy - an absurd estimate - this would represent a mere 1.4 per cent of the workforce. ${ }^{81}$

The lack of proportion and balance that is evident in discussions of independent contractors and the "gig" economy is perhaps even more

79. Audrey Vandenheuvel and Mark Wooden, "Self-Employed Contractors in Australia: How Many and Who Are They?" Journal of Industrial Relations 37, no. 2 (1995): 274; David Peetz and Alison Preston, "Individual Contracting, Collective Bargaining and Wages in Australia," Journal of Industrial Relations 40, no. 5 (2009): 444-61.

80. ABS, Characteristics of Employment, Australia, August 2016, Table 16.1.

81. For an overview, see Joshua Healy, Daniel Nicholson and Andreas Pekarek, "Should We Take the Gig Economy Seriously," Labour \& Industry 27, no. 3 (2017): 232-48. 
apparent in discussions of "neoliberalism," which has increasingly become the central explanation for union decline not only in Australia but elsewhere. Thus we are told that the Labor Party's embrace of "neoliberalism" since the 1980s means that unions can no longer hope for fundamental redress of social inequities through the political system, or, at least, through "a monogamous" union-Labor alliance; 82 that "in Anglo-Saxon countries ... governments and employers" have "turned their backs on unions through neo-liberal legislation and union-busting"; 83 that fear of the "New Right" caused Australian unions to accept "a less radical, but nonetheless neo-liberal, policy agenda" that caused them great harm. ${ }^{84}$ Rarely is the fundamental premise that Australia was launched on a "neoliberal" path by the HawkeKeating government subject to challenge. The only significant counter to this perspective that appears within the pages of Labour History is that by Collins and Cottle, who argue that the Hawke-Keating government was "neo-Laborist" rather than "neo-liberalist"; an argument that at least takes cognisance of this government's interventionist policies in terms of Medicare, compulsory superannuation, and (ultimately unsuccessful) industry policies to revive steel-making and automobile manufacture. ${ }^{85}$ Where definition is attempted, such as occurs in Gall, Hurd and Wilkinson's The International Handbook of Labour Unions: Responses to Neo-Liberalism, it typically involves sweeping generalisation; Gall, Hurd and Wilkinson declaring "neoliberalism" to entail "privatisation, marketization, liberalisation, deregulation, and reductions in state funding." 86 Now while this study (unlike Collins and Cottle) does not have a problem with the designation of the Hawke/ Keating government (and all its Australian successors) as "neoliberal," it does have difficulty with explanations that treat "neoliberalism" as if it was an all-destructive hurricane that obliterated the previous Keynesian and pre-Keynesian landscape. Nowhere can we see evidence of a society where long-established institutions of the welfare society have been destroyed. Even in the USA, as Figure 6 suggests, the various levels of government continue to employ the bulk of the nation's teachers, nurses and emergency service workers. In Australia and Canada, most university staff work in state-owned institutions. Across the OECD the share of GDP going to taxes has risen not

82. Ashley Lavalle, "The Ties That Unwind? Social Democratic Parties and Unions in Australia and Britain," Labour History, no. 98 (May 2010): 55-75.

83. Christian Lyhne Ibsen and Maite Tapia, "Trade Union Revitalisation: Where Are We Now? Where to Next," Journal of Industrial Relations 59, no. 2 (2017): 179.

84. Damien Cahill, "Business Mobilisation, the New Right and Australian Labor Governments in the 1980s," Labour History, no. 98, (May 2010): 20.

85. Joe Collins and Drew Cottle, "Labor Neoliberals or Pragmatic Neo-Laborists? The Hawke and Keating Labor Governments in Office, 1983-96," Labour History, no. 98 (May 2010): 25-37.

86. Gall, Hurd and Wilkinson, “Labour Unionism and Neo-Liberalism," 2. 
fallen, typically consuming around a third of the total. Of this total, 26 per cent on average comprises contributions to social security. ${ }^{87}$ That the state remains a significant factor in the Australian economy is ascertained by the fact that in August 2018 almost a third of Australian workers were employed in either healthcare and social assistance $(1,530,000)$, education $(968,000)$ or public administration $(811,600)$; areas that now comprise the great bulk of Australian union members. Without the comparative benevolence of the governments/employers in these three sectors, the union movement would not survive as a significant social force. ${ }^{88}$

If it is impossible to argue that the economic and occupational changes that have accompanied "neoliberalism" have been universally negative for organised labour it is nevertheless evident that this process of change has profoundly affected the areas in which unions have industrial appeal. That this is so is indicated by Figures 3, 4, 7 and 8. That the implications of this transformation are poorly understood is indicated by the ACTU's "campaign kit" for its Change the Rules policy. Overwhelmingly, this "kit" appears directed towards society's battlers, it being recorded that "trickle-down economics has failed to provide secure jobs, or fair wages." ${ }^{\prime 89}$ No doubt well intentioned, this "campaign kit" and likeminded strategies suffers from two interrelated problems. First, while it may have political utility in casting the current Coalition government as an agent of job insecurity, it is difficult to see it being industrially any more successful than were earlier campaigns among the low-waged sections of society. In areas such as hospitality (where union density stands at 3.5 per cent), agriculture (5.3 per cent), private-sector administrative and clerical work ( 5.46 per cent) and wholesale ( 4.7 per cent), unions simply no longer have the base of activists upon which industrial campaigns can be launched. Whatever strength unions do have in retail they owe, as we have previously discussed, to a "social partnership" with employers. The second problem is that one cannot see the appeal of the Change the Rules in high-wage areas, may they be in areas where unions are comparatively strong (public administration, education and health) or areas where they are extremely weak (finance, professional services). Thus, whereas 60 per cent of hospitality workers earn less than $\$ 25$ per hour, 58.2 per cent of workers in education earn more than $\$ 35$ per hour. The percentage earning in excess of $\$ 35$ per hour is even more pronounced in public administration (65.6 per cent), finance (61.5 per cent) and professional services (60.1 per cent). Yes, there is a minority of low-paid workers in these industries (teachers'

87. “Revenue Statistics 2017: Australia," OECD, accessed January 2020, www.oecd.org/ tax/revenue-statistics-australia.pdf.

88. ABS, Characteristics of Employment, Australia, August 2018, Table 3.1.

89. ACTU, "Change the Rules: Campaign Kit," 5-6, available on the NTEU website, accessed January 2020, www.nteu.org.au/library/view/id/8674. 
aids, casual tutors, etc.) but they are a minority. Only 12.8 per cent of workers in education earn less than $\$ 25$ per hour. In finance the comparable figure is 9.6 per cent. ${ }^{90}$ How are comparatively high-paid workers in these industries, many of whom enjoy long-term career and promotion prospects, to be won to unions? This is hardly a moot question, given that those employed in professional services $(788,800)$ outnumber those in hospitality $(779,700)$, and that those in finance $(406,100)$ easily outnumber those engaged in administrative and clerical work $(280,500) \cdot{ }^{91}$ There is, however, little indication that the ACTU is even aware of this question.

\section{Conclusion}

Writing in 1998, David Peetz, who has long enjoyed respected status for his opinions on union decline, rejected the idea that "union decline is inevitable or that ... Australian unions are heading down the American road" towards "union density of only 15 percent." ${ }^{92}$ In the years before and since this observation, Peetz's colleagues in industrial relations and labour history similarly put forward a series of explanations that suggested that union decline could be halted, if not reversed. Some explanations, such as the understanding that improvements in productivity should be an essential goal of workplace relations, no doubt benefited Australian society as a whole. Other explanations, informed by the idea that unions needed to improve their organising ability, were no doubt to the benefit of past and current members. But the fact that many of these explanations guided official union policy and, in the case of productivity bargaining, the fundamental orientation of our industrial relations systems - to no obvious beneficial effect in terms of union density, forces us to confront an alternative conclusion: that the process of decline is both inevitable and irreversible. If we accept that union decline is irreversible - union density now being less than the 15 per cent that Peetz once declared to be an avoidable outcome - than we need to stop focusing on explanations tied to remedies and look for deeper historical causes. In exploring the roots of union decline this article has argued that union demise can be traced back at least three generations to the late 1940s; a period that not only represented the peak of union strength but which also witnessed the first stages of the disintegration of the industrial working class that was the union movement's historical constituency. Between 1948 and 1986 - a period that saw union density fall from 64.9 per cent to 45.6 per cent - this article suggests that virtually all of the decline was probably due to the structural disintegration of the old industrial working class.

90. Calculated from ABS, Characteristics of Employment, Australia, August 2018, Table 3.2.

91. Ibid., Table 3.1.

92. Peetz, Unions in a Contrary World, 184. 
Since 1986, however, we have witnessed a more complex process of decline; a process in which residual support for unions among industrial workers has fallen away at a rapid rate during a period in which unions gained a new constituency in public administration, education and health. The most likely explanation for this post-1986 divergence is found in the fact that the extension of market forces in what most think of as "neoliberalism" made private-sector employers increasingly hostile to unions. By contrast, workers in public sector administration, education and health - concentrated in large, organisable units - were not only largely sheltered from such forces they also found that employers in these areas (even under conservative governments) were more benign than their private sector counterparts. One profound consequence of this post-1986 divergence is that Australian unionism was sociologically transformed, increasingly drawing its membership from parts of the society that were not representative of the whole.

If the simultaneous decline and transformation of Australian unionism has caused undoubted difficulties for the labour activist it also poses challenges for labour historians. Each of us, at some point, is confronted with the question: what is the relevance of my research and how can it inform activism? Inevitably, the answer to this question leads to the relationship between activism and scholarship, or rather, the distinction between the two. For activism by its very nature causes one to pay undue attention to immediate events, "the surface disturbances" that are, at best, but "surface manifestations" of "those underlying currents" that are profoundly altering our world. ${ }^{93}$ The call to be "relevant" is thus a dangerous siren cry that potentially leads the professional scholar away from their fundamental task, which is - as Copernicus wrote in the preface to his De Revolutionibus [On the Revolutions] - "to seek the truth in all things." ${ }^{14}$ As historians - as distinct from activists - this alone must be our goal.

Bradley Bowden is a labour and management historian. He is currently editorin-chief of the Journal of Management History, and co-editor in the Palgrave Macmillan Debates in Business History Series. He has twice won the Academy of Management's John F Mee Award for Outstanding Contribution to Management History. In 2016-17, he was Chair of the Management History Division of the Academy of Management. He has published histories of the Transport Workers Union, the Bacon Factories Employees Union and the United Firefighters Union (Queensland).

$<$ b.bowden@griffith.edu.au>

93. Braudel, "Preface to the 1946 edition," 21.

94. Nicholas Copernicus, De Revolutionibus, Calendars Through the Ages, WebExhibits, accessed January 2020, www.webexhibits.org/calendars/year-text-Copernicus.html. 